\title{
The Oil Market: Players, Challenges, and Opportunities
}

\begin{abstract}
Introduction
Growing concern over the ever-increasing price of oil makes investigating new approaches to oil policy necessary. In the last year the price of oil has increased sharply due to the instability and the political tensions in the Middle East. Such an increase in prices in a short time has significant implications for oil-dependent societies. It also means that major oil consumers like China and the United States invest in storing oil, which could result in more shortage and even higher prices. Although governments attempt to lessen their dependency on fossil fuel by investing in alternative fuels, in the short term they need to form strategies to cope with such unstable situations. New Zealand in this regard remains a unique case, with many underdeveloped oil reserves and a possible future as an active player in the international oil market.
\end{abstract}

At present New Zealand Oil \& Gas Ltd (NZOG) is involved in the Tui oil field project, with estimated reserves of up to 41.7 million barrels, and the Kupe gas/light oil condensate project, which has estimated reserves of 254 petajoules of sales gas, 14.7 million barrels of light oil/condensate and 1.1 million tonnes of LPG. According to NZOG, there are other offshore exploration projects with optimistic prospects (NZOG, 2008). An obligated member of the International Energy Agency, New Zealand is required to implement sets of co-operative strategies to counter market fluctuations and instability.

This article will describe the contemporary situation in the

Negar Partow is a PhD candidate in Religious Studies at VUW. She is a researcher in the Intelligence and Security Studies Research Unit of the School of Government, VUW, where she produces the weekly 'Security Monitor' on Middle East and North African politics, culture and economy. She also teaches in the Religious Studies and Strategic Studies programmes at VUW. Email: Negar.Partow@vuw.ac.nz global oil market and its implications for New Zealand energy security. It attempts to illuminate some of the issues connected with New Zealand oil policy by observing the forces and the main players in the global market. It surveys the oil market chronologically to explain how each player came to the global scene and how their policies shape the complicated oil market and industry.

The issue of energy security has dominated contemporary politics round the world. Under the pressure of soaring fuel and oil prices, politicians seek policies that minimise the negative implications of the sudden increase and ensure the security of energy. The security of energy resources is vital for the continuation of economic development and growth. The sudden increase in the price of oil in recent months has had several consequences for oil producers and consumers. To understand the reasons for such an acceleration in oil prices, the role of the main players in the global oil market, and their interactions and motivations, need to be identified. But first, some historical background. 


\section{The oil market}

During the last hundred years, since oil became a commodity in trade, the players in the market have often changed their policies and their association with other participants. These shifts are the result of changes in the political and historical context. In 1920 when a subsidiary of Royal Dutch Shell and Standard Oil of New York signed an oil contract in India, the profit of other major oil-producing companies, such as the Anglo-Persian Oil Company, was threatened. This resulted in the signing of a contract entitled the As Is Agreement at Achnacarry Castle in Scotland. This contract laid the foundation for the formation of the oil cartels. The cartels became significantly influential in determining the price of oil in later decades (Stevens, 2008). During the Second World War, with the exception of those in Russia and the United States, most of the oil reserves were under the control of the major oil companies known later as the seven sisters (Chapman and Khanna, 2006). These companies controlled both upstream (exploration, drilling, processing hydrocarbons into gas, condensate and oil) and downstream (refining and distribution) activities in the world oil market. Usually, contracts between the companies and the oil-producing countries were based on revenue that the oil companies were obligated to pay to the producing state.

After the Second World War the oilproducing countries gradually became aware of what they were losing with their existing contracts. The growing power of the oil companies was increasingly limiting the control of the producing countries over their activities and the price of oil. As the result of the As Is Agreement, oil field development in the Middle East was halted and exploitation of oil and its transfer to Canada and the United States increased (Sampson, 1991). During the process of the nationalisation of oil in Mexico and Iran, the power of the companies in isolating producing countries became evident (Parra, 2004, pp.25-7; Kobrin, 1985). Other oil-producing countries were also challenged by nationalist movements which centralised their activities with the nationalisation of natural resources, mainly oil (Odell, 1968).

At the same time, producing countries passed laws to limit the power of the companies over the income received for crude oil and its products. Under increasing pressure from both producing and consuming countries, the companies developed new strategies and established 'operating companies' to accommodate new policies and to lessen losses. These operating companies later became another influential force in determining the price of oil in the global market. The companies were established to enable the major oil companies to maintain their power over oil resources: following their establishment, a consortium of operating companies supervised the management of the oil resources. Companies in the consortium were aware of one anothers' activities. Consequently, the major oil companies extended their activities in the market. Major companies became involved in the domestic politics of the oil-producing countries in order to protect their interests and those of their respective countries.

A decade later the oil-producing countries became more powerful in the oil market. The unilateral contracts and tax system on oil were reviewed. Producing countries attempted to find customers who would sign contracts based on 'equal share' terms, and established national oil companies which became involved in oil activities under the supervision of their governments (McPherson, 2003, p.185). Most of the producing countries at this time used oil income as the main revenue for national economic development. Governments thus became directly involved in the process of distributing oil income as they transformed into complicated bureaucratic systems. They became rentier states, funded by rent they received from natural resources instead of tax. Many scholars argue that the oil rentier states became separated from the society, and that the oil rent retarded the process

of democratisation (Sandbakken, 2006). However, during the 1950s nationalist movements in the Middle East gave legitimacy to these national claims over resources.

After the Second World War, as countries like Japan and Italy rapidly industrialised they too became increasingly dependent on oil companies. Soon developing countries realised that to sustain development and economic growth, security of energy was vital. Their dependency on oil companies created a potential strategic threat which needed to be addressed. In order to counterbalance the power of the major oil companies, governments established national oil companies to counter the monopoly of the cartels in the market place. Furthermore, the formation of national oil companies in both producing and consuming countries was the result of mistrust of the cartels over the issues of the price of crude oil and distribution of its products.

As the battle between the major oil companies and governments continued, some new and small oil companies entered the oil market. These companies, mainly in the United States, were impelled by capitalist competitive market ideals. But in reality the hegemony of the major oil companies over resources left no place for their participation. The big companies' dominating power in the market enabled them to sabotage the activities of the smaller companies by breaking the price of imported crude oil in the United States. In order to break their monopoly over the oil industry, in the 1950s the United States Congress attempted to pass a law to increase the state's power over the major companies. Heated debates in Congress demonstrated how the issue of security was interconnected with 
that of state control over oil companies. After the failure of a voluntary import control plan, the Eisenhower administration established a mandatory 'oil import control programme' (Cox and Skidmore-Hess, 1999, p.92). With this programme the United States Congress supported independent oil companies in their struggle against the oil cartels. The United States became more directly involved in regulating the activities of the oil companies, valuing their products and reviewing their policies. Ironically, the legislation gave better opportunities to the operating companies to expand their areas of activities in the oil industry. organisation (OPEC, 2008). In the 1970s OPEG had about $90 \%$ of the world's operating oil reserves under its control. The organisation's priority was to counter the power of the oil cartels, and thus prevent any further decline in the price of oil.

The 'OPEC order' - 1974-1986 - refers to the time when the organisation became the main body for determining the price of oil and for instigating global economic shocks. Soon after the establishment of OPEC the strategic threat posed by such a powerful organisation became evident. Following the October 1973 war between Israel and Egypt and Syria (known in Israel as the Yom Kippur war and in the Arab countries as the Ramadan war), Arab oil-producing countries put the United States and the Netherlands under an oil embargo for their support of Israel. For the first time some producing countries used oil as a political tool in international politics. The oil shock that followed the embargo reshaped strategic thinking about energy security. In 1974 the price of oil jumped from \$US2.37 to \$US11.51 per barrel within a few months

The law passed by Congress and the limitation of oil imports to the United States had a negative impact on oilproducing countries. Although not the sole factor, the Congress decision motivated technocrats in oil-producing countries to challenge existing national oil strategies. They were by then aware of the significance of oil in the international market and national development. Following the nationalisation movements, they changed their oil strategies and encouraged independent oil companies to sign contacts which gave much greater shareholding to the producing countries in a strongly competitive environment. This ended the hegemony of the major oil companies over the market (Time, 1958, p.2). As the result of these new contracts and the formation of national oil companies, governments in producing and consuming countries achieved a more active role in the market.

\section{The formation of OPEC}

In order to counter the United States legislation on oil imports, Russia exported its oil on barter terms, offering technical and financial support in exchange for oil. Challenged by such lucrative oil deals, the power of oil-producing countries was more limited in the market. The battle between oil companies and governments, the United States oil legislation, Russia's oil policy, and competition amongst developed countries and their dependency on oil companies were some of the many issues that then faced oil-producing countries. The necessity of co-operation was a strategic and urgent reality. None of the producing countries could face these challenges in isolation. For this reason, an intergovernmental Organisation of the Petroleum Exporting Countries - OPEC - was established. The organisation aimed to make oil-producing countries more influential in the oil market. Between May 1960, when Venezuela, Iran, Iraq, Saudi Arabia and Kuwait agreed on the foundation of OPEC, and 1975, 11 countries joined the
(CBC, 2007). This was the first oil shock that spread economic recession throughout the world, especially in the United States. At the same time, the United States government continued support for legislation regarding the limitation of oil imports into the United States. ${ }^{1}$ Although in the following decades OPEC faced inter-organisational challenges as well as external pressures, it remains to this day a very influential organisation in the oil market.

During the 1980s, due to disagreements amongst members, political confrontation, and the bombing of both Iran and Iraq's oil infrastructures, OPEG lost power. Moreover, members of OPEC are competitors in the market and the organisation is sometimes dominated by one or other of them. During the 1980s Saudi Arabia became the organisation's dominant voice. This factor is crucial in identifying OPEG policies that affect the price of oil. Members of OPEG are divided into two groups, usually referred to as the 'hawks' and the 'doves'. The member countries have different interests in the market and consequently have differing views regarding the limits of production and the price regime.

Saudi Arabia and Kuwait are countries with vast oil reserves and small populations. For these countries - the doves - increasing production with cheaper prices is the goal of their OPEC policies. They argue that by increasing the market share, they can, in the long term, achieve their economic goals. They encourage more production, which, as it needs more investment in upstream activities, benefits them and the development of their oil industry. Other countries, such as Iran, Nigeria and Iraq, support a decrease in production and higher prices. These countries - the hawks - have smaller oil reserves and larger populations. They argue that saturating the market with oil will not guarantee more investment and may instead have a negative impact, as supply outstrips demand (Scanlon, 2003). OPEG oil policies are influenced 
by these contradictory strategies. It was only in the late 1990s that members of OPEG decided on a price range mechanism aimed at keeping the price per barrel between \$US22 and \$US28. They did this by controlling the amount of crude oil they exported. The determination of the price was based on technical issues rather than geopolitical concerns. The members decided that reductions or increases in production should depend on demand.

The political interactions amongst the members of OPEG have influenced the production and the price of oil. For OPEC members, most of whom have a 'one product economy', the economic impact of market fluctuation extends into every area of their economy. OPEC policies in the last four decades have not been harmonious or at ease. In many circumstances, political disagreements among the members have created fluctuations in the market. These fluctuations, the growing power of the International Energy Agency and its members, especially the United States, and competition among multinational oil corporations have reduced the power of OPEC and this in turn has affected its members' national policies.

OPEC is viewed by the West as a powerful cartel which should be countered. In May 2007 the United States House of Representatives passed a bill that would allow the Justice Department to sue members of OPEC for applying an anti-competitive practice (the price range mechanism) to the oil price. John Conyers, the House Judiciary Committee chairman, introduced the No Oil-producing and Exporting Cartels (NOPEG) Bill, and blamed cartels like OPEG for the soaring oil prices. The United States Senate Judiciary Committee signed off on similar legislation in April. Similar bills were vetoed by the White House in 2000, 2004 and 2005. The White House may also veto the recent bill, which it believes will put upward pressure on the price of gasoline by disrupting supply (Randell, 2007).

\section{The formation of the International Energy Agency (IEA)}

In November 1974, in order to counter the power of OPEC, the main consuming countries formed the International Energy Agency in Paris. The IEA was formed within the framework of the Organisation for Economic Co-operation and Development (OECD) and the members of the OECD became members of the IEA. The main goal of the agency was to provide security for energy distribution to consuming countries. Later, the organisation's activities expanded to include environmental issues, carbon emissions and encouraging the use of alternative energy sources. Its first mission, however, was to establish policies to counter future oil shocks like the one in 1973 (IEA, 2008). Although not very successful in dealing with the aftermath of the first oil shock, the IEA proposed policies to minimise the negative impact of oil shocks in the future. It placed significant emphasis on creating policies to harmonise the energy policies of its members and to eradicate differences amongst them.

The agency analyses - in both official and unofficial ways - issues which are vital to the management of oil crises. Sharing oil amongst the members in times of crisis and the strategic storage of 90 days worth of oil are among the agency's pre-emptive measures to deal with future oil shocks (Richardson, 2008, p.14). In 1979, the second oil shock was an inevitable outcome of the Iranian Revolution. The policy of organising a co-operative response to oil shocks or any severe disruption of oil supply prevents the isolation of any one country. Obviously, the IEA is acutely aware of the competitive and privatised nature of capitalist economies and of the implications of any oil crisis. The members agree that in times of emergency governments are obliged to intervene in the market. The agency strongly emphasises co-operation amongst its 27 member countries. This policy is based on the premise that oil-consuming countries are mutually dependent in the matter of energy security. In this role the IEA became the buffer zone between OPEC and the consuming countries and between the cartels and consuming countries.

\section{...a comparison of Norway's oil policies with those of other oil-producing countries can show how oil revenue policies which are not rentier ones can achieve societal benefits.}

The IEA has also developed policies to encourage the use of alternative energy, initiated carbon taxes to reduce environmental pollution, and encouraged another tax on the exploration industry. The latter slowed the process of exploration in the 1990s which has been an influential factor in raising the price of oil. The decrease in investment and in exploring activities over decades resulted in the reduction of OPEC capacity for production. The taxes implemented by the IEA enabled the consuming countries to gain more benefit from importing oil than the producing countries of OPEC from exporting crude oil (Toman, 2002, p.21). However, in the 1990s there was no significant oil shock to test the IEA's policies on dealing with market fluctuations. In recent decades their emphasis on alternative sources of energy, reducing carbon emissions and investing in oil exploration in the nonOPEC countries has had a significant impact on limiting the power of OPEG in the oil market. However, this policy has had a longer-term negative impact on the oil market. Since 2003 the reduction of the resources of non-OPEC members has created a gradual vacuum in the market. This vacuum is the result of the lack of investment in OPEC countries. They are now incapable of increasing supply, due partly to the lack of infrastructure (Oxburgh, 2008). ${ }^{2}$ 
At the time that the IEA began operating in the market the first oil shock was over, so the focus of its policies was to structure a system that would reduce the possibility of another shock (IEA, 2008). The IEA focused on alternative energy and increasing oil exploration activities to find new oil reserves in consuming countries like Norway and New Zealand. Exploration for oil in Norway sped that country's development. Norway discovered oil resources after the process of development and did not directly funnel its oil revenues into national development (Larsen, 2004, p.13). It created a reserve account under the supervision of the ministry of finance, which enabled the government to strengthen its monitory role in the industry without being directly involved in distributing rent. Domestically, oil did not turn into a black curse for Norway (Martinovits, 2002). producing countries, an increase in the cost of producing a barrel of oil, and the decrease in the value of the US dollar resulted in a sudden increase in the oil price. ${ }^{3} \mathrm{~A}$ similar oil shock to the one that created a global recession in the 1970s started in 2003 when the price of oil increased from \$US22 to $\$$ US58 per barrel. Since 2003 the price of oil has increased from $\$$ US58 to over $\$$ US125 per barrel. The rise in prices has affected the position of OPEC in the oil market.

In most of the analysis regarding the sudden increase in oil prices, the focus is on observing competitiveness amongst main consumers, and the rise of demand especially from booming economies in China and India (Richardson, 2008; Neilsen, 2008; Aldred, 2008). Neither China nor India is a member of the IEA. Thus, neither is obliged to accommodate their oil policies to IEA policy regulation. The rise of China as the biggest consumer of oil next to the United States has had a negative impact on the status of the United States. The more a country uses energy, the more developed it is; thus, if China overtakes the United States in using oil its rate of growth will be higher than that of the United States. Since the advent of the oil industry the United States has been the largest consumer, one of the main producers, and has an elite status in the market. The involvement of US oil companies in the international market, and the country's

In less than a decade after the exploration of oil Norway moved from the bottom to the top in OECD rankings. Implementing egalitarian policies and a combination of national control along with the capitalisation of the oil industry made Norway $60 \%$ richer. Norway is currently ranked as first in the United Nations Human Development Report. The oil revenues have contributed to a more equal distribution of wealth. Lack of corruption in a solid democratic state, focusing on education as a key priority, and an emphasis on an anticorruption mentality are some of the main factors that have made Norway successful. Transparency and accountability in government created confidence for building and managing public institutions and expectations (Larsen, 2004, p.24).

Norway's oil contracts are very simple. The government receives a $75 \%$ tax from both domestic and international companies. Revenues saved in the reserve bank are mainly spent on education, health services, and Norway's involvement in the global oil market. Although it is not the focus of this article, a comparison of Norway's oil policies with those of other oil-producing countries can show how oil revenue policies which are not rentier ones can achieve societal benefits.

\section{The contemporary context}

It is clear that since 2003 OPEC has been increasing its influence in the oil market. This is to some extent the result of regional instability, conflicts, lack of infrastructure and investment in upstream activities, and the rise of China and India as competitors for the United States. In addition to these factors, reduction in production capacities of non-OPEC military and diplomatic capabilities have also contributed to its high status. Since the exploration of oil in the Middle East, the United States has had naval ships in the Persian Gulf to ensure the security of supply. At the national level the United States' control over oil prices is a practical way of controlling the world's economy. It is due to this strategy since the 1950s that the United States established a very close political relationship with Saudi Arabia, the world's major oil producer.

Being a member of the IEA and also a producer, the United States has been able to influence oil prices from both sides. For decades the United States remained the most influential country in the oil market. The rise of China reshapes this political structure. China imports most of its oil from the Persian Gulf, and because the United States has a military presence in the Persian Gulf any tension in the US-China relationship could result in economic disaster for China. In order to counter this potential security threat China has invested in contracts with Russia, Iran, Chad and Nigeria in order to diversify its energy sources. Chinese companies do not demand involvement in the national politics of the producing countries. By not overtly combining politics with economics, China has gained advantages in countries like Chad and Nigeria. China's Achilles heel is, however, the increasing number of cars. Rising fuel prices could slow China's development mechanism, as the country would be forced to spend more on crude oil and fuel (Renner, 2006). So the United States may yet achieve strategic advantages over China as a result of the rising price of oil. 


\section{Oil speculators}

These speculators are commodity traders who began their activities in the oil market in the 1980s. Before then, most contracts were decided and signed by commodity producers and those who used the actual products. The expansion of the market and the increase in the value of oil and its products have reshaped the market. During the last three decades many industries and even industrialised countries have been purchasing oil ahead. Speculators buy and sell future contracts for oil for future delivery. These contracts are deals on paper, under which the buyers are committed to purchase the sum of oil indicated in the contract in the indicated time, and the producer is committed to deliver the oil to the buyer. Trading the contracts is where the speculators could manipulate the market and influence the crisis. Speculators determine the price of oil based on their estimation of the future of the geopolitics of the region and possible available resources in the future. They are more influential in creating short-term oil shocks than in establishing longer-term trends.

Most of the trades in the future are signed by industrial players, mainly within the oil industry. In this fashion they can ensure the continuity of the flow of oil to their industry in future. Purchasing future oil contracts minimises the risk as any extra purchase of oil can be re-sold in the market. Although such a system is very effective in ensuring the future of an industry, not all the contracts in the market are materialised in real purchase or delivery. Some speculators would benefit not from contracts but rather from market fluctuations. For these players it is not necessarily the high price of oil but rather the fluctuation in the market that ensures their benefit. The fact that the energy market has a very low risk of investment compared to, for example, the mortgage market has motivated many to place their investment in the energy market. Billionaire investor George Soros, in a July 2008 address to American legislators, indicated that the rising price of oil is significantly the result of the increasing involvement of investment institutions in the market as oil speculators (Chung, 2008). It is clear that speculators play a significant role in market fluctuations, and with economic downturns in the food, housing and financial sectors they will be more active in the market. Their presence in the market will result in more market fluctuations, specifically in the oil market where there is no clear picture regarding accessible or existing resources. They increase an artificial demand for a commodity which will inevitably increase the oil price. However, competition among their increasing numbers may from time to time result in small decreases in the oil price.

\section{Implications for New Zealand's oil future}

According to the IEA website, New Zealand's energy demand is increasing. About $50 \%$ of New Zealand energy is supplied by imported oil and its largest domestic source of oil (the Maui oil fields) is running out steadily (Natusch, 2008, p.57).
According to the BP statistical review (2007), New Zealand oil imports increased by $1.2 \%$ from 2005 to 2006 . It should be noted that these statistics only relate to crude oil importation and do not cover countries' indirect economic dependency on oil. As the price of oil increases the cost of most if not all imported products will also increase. This will have a negative impact on the domestic economy and eventually on exports. Although imported oil presents the biggest challenge that the New Zealand energy sector is facing, the economic implications of higher prices are not confined to the energy sector. Evidence of this has already become clearly apparent in the areas of transport and food.
New Zealand Oil \& Gas argues that New Zealand has an exciting future in the energy market, in light of its underdeveloped oil and gas reserves. Whether it is a consumer only or a non-OPEC producer, New Zealand needs foreign investment to develop or sustain its oil industry. Thus it needs to closely observe interactions between the main players and their influences in the market. The activities of OPEC and non-OPEC oil-producing countries show that inviting foreign investment will have economic and political consequences that need to be carefully assessed beforehand. In this regard, Norway's experience in managing resources through combining national and capitalisation policies presents a successful model. Investing oil revenues in the health and education sectors and training professionals to participate in the international oil market are opportunities that the developing oil industry in New Zealand can offer.

The nationalisation of oil in Middle Eastern oil-producing countries has led to governmental rentier policies. Moreover, nationalisation extended governments and made them reliant on the rent from natural resources. However, limiting the New Zealand government's monitory role over the development of this country's oil industry could have a negative impact on the economy. The lack of government involvement in the activities of the industry will minimise its ability to ensure that the public will receive benefits from such developments. The Norwegian government's involvement in its country's oil industry and receiving tax from investing companies enables the government to monitor investors. Experiences in oil-producing countries demonstrate that such monitoring systems are vital to ensure the best use of natural resources. If it is fully involved in oil contracting processes, the New Zealand government will be better able to guarantee economic benefits for the health, education, and other, sectors. 


\section{Conclusion}

As discussed in this article, main players in the market and their national policies, organisations like OPEC and the IEA, major oil companies and speculators all influence the price of oil and market fluctuation. Competition among the main players at national and organisational levels over consumption places more pressure on producing countries to increase production. Lack of infrastructure, competition among producers and concerns over geopolitics and the peak of oil have limited production capacity. ${ }^{4}$

Fluctuations in the oil market will continue. However, there are factors that may slow the rapid increase in the price of oil. It is evident that returning to the beginning of 2007 when oil was \$US50 a barrel seems impossible, but progress in the security situation in the Middle East would push the price down. The possibility of the resumption of Iran-US political ties, improvement in the security situation in Iraq, and investment in oil developing projects could all ease the contemporary situation. The existing situation reminds governments that the energy market is vulnerable and susceptible to fluctuations. The IEA policies on keeping oil savings and encouraging co-operation amongst consumers helped the governments decide on more harmonious policies. But these policies have not been very successful in handling the current oil crisis, which reflects the increasing number of players in the oil market and its interconnection with the global economy and international security.

For consuming countries, ensuring the sustainable supply of energy is vital to economic development and national security. Besides encouraging efficient use of energy, developing alternative sources and co-operating with the IEA, in times of crisis governments need to intervene in the market in order to limit the negative effects of economic recession in the shorter term.

\footnotetext{
1 The Arab oil embargo of 1973, Emergency Petroleum Allocation Act 1973, Energy Policy and Conservation Act 1975 and the creation of the US Department of Energy in 1977. See http://www.eia.doe.gov/pub/oil_gas/petroleum/analysis_publications/chronology/ petroleumchronology2000.htm.

2 Lord Oxburgh was chairman of Shell from 2004 to 2005.

3 For further information on the decrease of oil production in non-OPEC producers, with reference to New Zealand, see IEA, International Energy Annual, Short Term Energy Outlook, Table 3a, Table 3b (forecast values).

4 Many producing countries, mainly the hawks, argue that there is enough oil in the market as the result of the pressure of the United States and the United Nations on Saudi Arabia. The latter has promised to increase production, but only by 200,000 barrels a day. Such a minor increase prompts speculation over Saudi Arabia's production capacity.
}

\section{References}

Aldred, K. (2008) 'Energy security and external relations', in B. Lynch (ed.), Energy Security: the foreign policy implications, Wellington: New Zealand Institute of International Affairs

CBC (2007), 'Oil: the price of oil marching to \$100?', 18 July, www.cbc.ca/news/ background/oil, accessed on 15 June 2008

Chapman, D. and N. Khanna (2008) 'The Persian Gulf, global oil resources, and international security', Contemporary Economic Policy, 24 (4), pp.507-19

Chung, J. (2008) 'Soros sounds alarm on oil bubble', Financial Times, 3 June, http:// www.ft.com/cms/s/0/5dbdOffe-30ef-11ddbc93-000077b07658.html?nclick_check=1

Cox, R. and D. Skidmore-Hess (1999) Politics and the Global Economy: corporate power, conservative shift, Boulder: Lynne Rienner Publishers

International Energy Agency (IEA) (2008), www. iea.org/about/index.asp

Kobrin, S. (1985) 'Diffusion as an explanation of oil nationalization: or the domino effect rides again', Journal of Conflict Resolution, 29 (1), pp.3-22

Larsen, E. (2004) 'Escaping the natural resource curse and the Dutch disease? Norway's catching up with and forging ahead of its neighbors', http://elsa. berkeley.edu/pub/users/webfac/cbrown/ e251_f03/larsen.pdf

McPherson, C. (2003) 'National oil companies: evolutions, issues, outlook', in J. Davis, R. Ossowski and A. Fedelino (eds), Fiscal Policy Formulation and Implementation in Oil-producing Countries, Washington: International Monetary Fund

Martinovits, A. (2002) 'Audit of the Norwegian Government Petroleum Fund', International Journal of Government Auditing, April

Natusch, D. (2008) 'New Zealand energy reserves as strategic assets', in B. Lynch (ed.), Energy Security: the foreign policy implications, Wellington: New Zealand Institute of International Affairs

Neilson P. (2008) 'Facing the future: three challenges', in B. Lynch (ed.), Energy Security: the foreign policy implications, Wellington: New Zealand Institute of International Affairs

New Zealand Oil \& Gas Ltd (NZOG) (2008), www.nzog.org.nz, accessed on 22 June 2008

Odell, P. (1968), 'The significance of oil', Journal of Contemporary History, 3 (3), pp.93-110

OPEC (2008), www.opec.org/aboutus/history/ history.html

Oxburgh, Lord (2008), BBC 'Hard Talk' interview, 10 June, http://news. bbc.co.uk/2/hi/programmes/ hardtalk/7446670.stm

Parra, F. (2004) Oil Politics: a modern history of petroleum, London: I.B. Tauris

Randall, M. (2007) 'Taking on OPEC: House passes "NOPEC” Bill', Wall Street Journal, 22 May, http://blogs.wsj.com/ washwire/2007/05/22/taking-on-opechouse-passes-nopec-bill/

Renner, M. (2006) 'The new geopolitics of oil', Development, 49, pp.61-3

Richardson, M. (2008), 'Asia-Pacific energy security: the Middle East nexus', in B. Lynch (ed.), Energy Security: the foreign policy implications, Wellington: New Zealand Institute of International Affairs

Sampson, A. (1991) The Seven Sisters: the great oil companies and the world they shaped, New York: Bantam

Sandbakken, C. (2006) 'The limits to democracy posed by oil rentier states: the cases of Algeria, Nigeria and Libya', Democratization, 13 (1), pp.135-52

Scanlon, T. (2003) 'OPEC: the oil cartel', http://news.bbc.co.uk/2/hi/ business/689609.stm, accessed on 18 June 2008

Stevens, P. (2008) 'National oil companies and international oil companies in the Middle East: under the shadow of government and the resource nationalism cycle', Journal of World Energy Law and Business, 1 (1), pp.5-30

Time (1958) 'The Shah's gamble', www.time.com/time/.magazine/ article/0,9171,864511-1,00.html, accessed on 20 June 2008

Toman, M. (2002) 'International oil security problems and policies', The Brookings Review, Spring, 20 (2), pp.20-2 